\title{
Democracy or control? The participation of management, teachers, students and parents in school leadership in Tigray, Ethiopia ${ }^{1}$
}

\author{
Rafael Mitchell (rafmitchell@gmail.com) \\ School of Education, University of Leicester ${ }^{2}$
}

In Ethiopia, as elsewhere in sub-Saharan Africa (SSA), there are efforts to broaden local stakeholder participation in structures and processes of school leadership. Despite advocacy from the World Bank, amongst others, research in SSA questions the extent to which such reforms reflect genuine democratisation. This study applies theories of power to the participation of local stakeholders (management, teachers, students and parents) based on ethnographic fieldwork conducted at a government primary school in Tigray. The study finds that management agendas dominate consultative and decision-making forums; however, these spaces also enable students and others to share their views on conduct within the school community, which serves an important accountability function.

Keywords: accountability; community participation; democratisation; Ethiopia; ethnographic case study; power analysis; school-based management; school leadership; student voice; sub-Saharan Africa

\section{Introduction}

Like its neighbours across sub-Saharan Africa (SSA), Ethiopia has committed to providing free, compulsory schooling for young people aged 7-14. The expansion of the primary school system over the past two decades has strained resources and provoked concerns about declining educational quality (Tekeste 2006; MOE 2008, 2015) which are familiar elsewhere on the continent (Lewin 2009). Expansion has occurred at extraordinary speed and scale. Since the early 1990s primary enrolment has increased from 3 to 18 million students, and the number of primary schools has increased threefold since the start of the millennium (MOE 2015). Over this period Ethiopia has gone from having one of the lowest rates of educational participation in the world (UNICEF 1997) to enrolling an estimated $85 \%$ of young people aged 7-14 (ODI 2011). Roughly three-quarters of students complete Grade 5, and half complete Grade 8, the final year of primary school (MOE 2012, 2015). In response to this rapidly changing profile of schooling, the Government of Ethiopia has instituted policies aimed at increasing stakeholder participation in school-based management (SBM). These include policies for cost-sharing (MOE 2005), the establishment of Parent Student Teacher Associations (PSTAs) (MOE 2015), and school self-evaluation and improvement planning (MOE 2007, 2010).

The means through which parents, students and others are involved in school leadership can be thought of as 'participative spaces', defined as: 'opportunities, moments and channels where citizens can act to potentially affect policies, discourses, decisions and relationships which affect their lives and interests' (Gaventa 2005, 11). The last two decades have seen a proliferation of participative spaces in public services across the global South (Gaventa and McGee 2013). Community participation in SBM is now commonplace in SSA (Khan 2006;

\footnotetext{
1 (C) 2017. This manuscript version is made available under the CC-BY-NC-ND 4.0 license http://creativecommons.org/licenses/by-nc-nd/4.0/. This is a post-print version of an article to be published in the International Journal of Educational Development. DOI: 10.1016/j.ijedudev.2017.05.005.

${ }^{2}$ Current affiliation: Faculty of Education, University of Cambridge.
} 
Daun and Mundy 2011). As such, the reforms described above are not so much Ethiopian as global education policies (Verger, Novelli and Altinyelken 2012), advanced by hegemonic Western policy actors such as USAID, DFID and the World Bank (Tabulawa 2003; Mitchell 2015; Zapp 2017). The World Bank has argued that parental involvement in decision-making processes

encourages demand for a higher quality of education and ensures that schools reflect local priorities and values. By giving a voice and decision-making power to local stakeholders who know more about the local education systems than do central policy makers, decentralization can improve educational outcomes and increase client satisfaction. (Barrera-Osorio et al. 2009, 2)

The validity of these claims in relation to the voice and influence of local stakeholders will necessarily depend on the nature of participative spaces in school: the means of involving parents and others in processes of consultation, evaluation, and decision-making. This article focuses on these concerns by addressing the question: how is the participation and influence of the key stakeholder groups achieved and mediated by structures and processes in school?

\section{Broadening participation: distributed leadership and democratisation}

Calls for broadening participation in school leadership resonate with literature on distributed leadership (DL) and democratisation. From an analytic DL perspective, leadership is an emergent property of a group or organisation: it is a practice, rather than a position, which crosses formal hierarchical boundaries and professional and non-professional designations (Woods and Woods 2013). Researchers have long argued for leadership which capitalises on knowledge, experiences and perspectives from across the school (MacBeath 1999; Rudduck and McIntyre 2007; Deakin Crick et al. 2016). From an instrumental perspective, members of the school community are a valuable asset, part of the school's 'intellectual capital' (Hargreaves 1999). Mobilising the community's 'ideas, creativity, skills and initiative...unleashes a greater capacity for organizational change, responsiveness and improvement' (Woods 2004, 5). Such participation could ensure that school development reflects local values and priorities - or else, it could be 'extractive', using the community as a source of labour and materials (Rose 2003).

Exercising leadership in school is associated with a heightened sense of agency, belonging, and social competence amongst students and staff (Fielding and Prieto 2002; Mitra 2004; MacBeath and Dempster 2009; Woodhouse and Pedder 2016) and feelings of ownership amongst parents (Swift-Morgan 2006, 365; Jeilu 2009, 55). Since democratic values are best developed experientially rather than through a disembodied political curriculum (Harber 2002; Fielding and Prieto 2002; Harber and MnCube 2012), many have argued that broadening participation in decision-making is an important means of promoting democracy in schools and wider society (Davies, Schweisfurth and Harber 2002; Woods and Woods 2013). Understandings of democracy are culturally and temporally situated (Crick 2002). Democracy is best understood as 'a set of political processes towards the ends of justice, prosperity and peace' (Davies 1999, 124). The following elements are key to most definitions of democracy:

- Rights - a set of entitlements common to all individuals

- Participation - the free involvement of individuals in the decision-making process 
- Equity - fair, equal treatment of individuals and groups

- Informed choice - the capacity to make decisions based on relevant information and reason (Davies, Harber and Schweisfurth 2002, 4-9)

Clearly, broad participation in decision-making is a necessary but not sufficient condition for democratic school leadership.

\section{Participation in practice: evidence from empirical studies}

Since the early years of this century, empirical studies in the global North and South have challenged the World Bank claim that community participation 'ensures that schools reflect local priorities and values' (Barrera-Osorio et al. 2009, 2). In case studies of DL at two elementary schools in Texas, USA, Maxcy and Nguyen (2006) found that the dominant theoretical models of DL neglect the political dimensions of leadership distribution. They stress the need to distinguishing between distributed and democratic leadership in which there is 'collective and deliberative determination of means, modes, and ends of schooling' (ibid., 164). The leadership practices they encountered in Texas were

less arrangements to transfer power to those down in the chain of command...than means to maintain the status quo, if not further consolidate power under the guise of redistribution. (ibid.,181)

In practice, DL amounted to the delegation of tasks and responsibilities in service of management agendas. There have been similar findings in the UK context (Woods 2004; Hatcher 2005; Harris 2013).

Studies in SSA over the same period highlight discontinuities between national policy rhetoric about democratisation (accountability, ownership) and local understandings and practices of participation (Suzuki 2002; Rose 2003; Pryor 2005; Swift-Morgan 2006; Taylor 2009; Yamada 2014; Masue and Askvic 2016). These studies identify challenges to democratic participation within and beyond the school walls. Firstly, the inequitable status of different groups in school is at odds with the principles of democracy outlined above. In Oromia (central Ethiopia), Swift-Morgan (2006) found that teachers perceived parents as lacking the necessary knowledge to engage in school leadership processes: 'The educated cannot be evaluated by the uneducated', as one teacher explained (355). Elsewhere in the region, studies find that females are underrepresented on governing bodies and less vocal than their male counterparts (Rose 2003; Khan 2006). Although there are no previous studies of student participation in school leadership structures in SSA, their subordinate status in relation to teachers is widely documented (Poluha 2004; Omolewa 2007). For example, in rural Ghana, Adzahlie-Mensah (2014) found that students came to view themselves as 'nobodies' with no rights as a result of routine violence and authoritarianism in school (cf. Harber 2004). These studies suggest contexts unconducive to the democratic principles of rights and equity.

A second challenge to democratic participation is the lack of school autonomy in relation to district authorities (in Ethiopia, the Woreda Education Office). In Tanzania, Taylor (2009) found that although parents contributed to the production of school development plans, these documents were simply left to gather dust in the District Education Office. Funding from Western donors was conditional on schools producing these documents (cf. Tabulawa 2003), but the plans did not inform actual spending decisions. This is an example of 'pseudo- 
participation' (Ball 1987, 125; Rose 2003) or 'democratic cosmetics' (Masue and Askvic 2016).

The above studies of participation in SSA illustrate how power relations internal and external to the school 'shape the boundaries' of participative spaces, affecting 'what is possible within them, and who may enter, with which identities, discourses and interests' (Gaventa 2006, 26). Each of these studies challenges the claim that local stakeholder participation provides an assurance that schools reflect local values and priorities. These studies share two common limitations. Firstly, they focus on the participation of parents to the neglect of other stakeholders, such as teachers, management and students (the latter perhaps more relevant in the Ethiopian context). Secondly, they offer minimal description or analysis of the participative spaces (sites, contexts, structures) through which stakeholder participation is achieved and mediated in school. The present article explores these issues in the Ethiopian context.

\section{Study design}

This article draws from an ethnographic case study of the agendas, participation and influence of local stakeholders - management, teachers, students and parents - at an urban government primary school in Tigray, Ethiopia. The full report of this $\mathrm{PhD}$ research, which is freely available online, contains a 'research biography' (Ball 1990) detailing the design and implementation of the study (Mitchell 2017a, chapt. 3). The study was informed by previous ethnographic school research (e.g. Hargreaves 1967; Wolcott 1967; Ball 1981; Burgess 1983; Poluha 2004). Fieldwork involved studying activities first-hand and recording observations in fieldnotes (FNs); developing data through open-ended, informant-led interviews (Wolcott 1995, 102); collecting institutional documents; and pursuing the development of the research through progressive focusing (Hammersley and Atkinson 2007). This was 'focused' rather than conventional ethnography (Knoblauch 2005); it involved 6 months' data collection over an 8-month period (rather than a full year) and focused on previously-identified aspects of school life: stakeholders' agendas, participation and influence.

In Ethiopia, the Ministry of Education (MOE) establishes the national policy framework, but many aspects of policy and practice are decided at the regional level. There are wide disparities between regions in terms of class size and material conditions (Mitchell 2017a, 1920), and practices in Tigray are likely to diverge from those in other regions. As such, further research is needed to establish the relevance of the practices and conditions described in this study to schools elsewhere in the country. Moreover, a single school case study provides no basis for statistical generalisations to other schools in the region; the grounds for wider relevance are naturalistic generalisations (Stake 1995).

The study was conducted at Ketema School (pseudonym), a government institution serving 1300 students mostly aged 7-16 years, from households headed by merchants, domestic workers, civil servants, drivers, and those without formal employment. As a large school, Ketema has three members of management - a Director and two Vice Directors (all male) - and 46 teachers, divided equally by gender. Located in the heartland of the Tigrayan People's Liberation Front (TPLF), the dominant partner within the ruling national coalition (Vaughan 2011; de Waal 2013), all management positions are occupied by members of the Party, which also holds majority seats in all the senior committees (cf. Berihu and Mewcha 2015). Data collection took place in 2014 and focused on the meetings of various bodies, and 
the activities of a single class in Grades 6 and 7. The 'case data' (Stenhouse 1978, 37) comprises 500,000 words of typed FNs, 2000 photographs, and data from more than 100 lesson observations and 38 meetings. This was analysed inductively and thematically (Braun and Clarke 2006) using Atlas.ti. Constructs developed through this analysis were linked to the theoretical literature, especially the work of Lukes $(2005)$, Gaventa $(2005,2006)$ and Foucault ([1977] 1995), as outlined below.

\section{Findings}

Two important contexts of stakeholder participation in school leadership are:

- Positions of distributed leadership through which teachers, students, and parents take on additional responsibilities within the school community.

- Meetings of various bodies, including consultative, evaluative, and decision-making forums.

Stakeholder participation in both contexts is considered below.

\subsection{Distributed leadership and social control}

At each level of the school community there are formal positions of distributed leadership (DL) through which teachers, students, and parents share responsibility for maintaining and improving conditions in school, and supervising others' conduct in line with management agendas and external policy requirements (cf. Ehren et al. 2016, 6).

Table 1 Distributed leadership positions

\begin{tabular}{|l|l|l|}
\hline Stakeholder & Position & Description \\
\hline Teachers & Unit leader & $\begin{array}{l}\text { 2 or 3 teachers, elected by colleagues or appointed by } \\
\text { management for an annual term. Surveillance role, handling } \\
\text { cases of student/teacher misconduct; reporting to } \\
\text { management. }\end{array}$ \\
\cline { 2 - 3 } & $\begin{array}{l}\text { Head of } \\
\text { Department }\end{array}$ & $\begin{array}{l}\text { Communicate management instructions to departmental } \\
\text { colleagues and monitor compliance. Produce monthly } \\
\text { reports on departmental activities according to school plan. }\end{array}$ \\
\hline Students & Monitor & $\begin{array}{l}\text { 2 per class (1 male, 1 female) elected by peers for an annual } \\
\text { term. Supervise student conduct and undertake } \\
\text { administrative duties (e.g. recording attendance and } \\
\text { misdemeanours, arranging club lists). }\end{array}$ \\
\cline { 2 - 4 } & $\begin{array}{l}\text { Network } \\
\text { leader }\end{array}$ & $\begin{array}{l}\text { Around 7 per class, top-ranking students assigned to support } \\
\text { the 5-6 students at their desk. Support academic learning } \\
\text { (e.g. sharing work, explaining concepts), facilitate group } \\
\text { work in lessons (e.g. as scribe, chairperson). }\end{array}$ \\
\hline Parents & $\begin{array}{l}\text { PSTA } \\
\text { representative }\end{array}$ & $\begin{array}{l}\text { 3 or 4 parent representatives on the governing body. } \\
\text { Monitor management processes (e.g. exam results, teacher }\end{array}$ \\
\hline
\end{tabular}




\begin{tabular}{|l|l|l|}
\hline & $\begin{array}{l}\text { performance appraisals), identify development priorities, } \\
\text { control the budget. }\end{array}$ \\
\hline
\end{tabular}

The leadership positions in Table 1 pertain to diverse aspects of school life. Each position serves multiple functions (e.g. providing academic support, undertaking administrative duties), but a social control function is common to all. In each case, post-holders supervise and regulate the behaviour of peers and colleagues, promoting conduct in line with management agendas (cf. Maxcy and Nguyen 2006). This point is illustrated with reference to one teacher and one student leadership position.

Unit leaders monitor the work of their colleagues and report to management. They patrol the grounds with a notebook, recording infractions such as teachers missing morning Flag Ceremony or leaving school early. If they find a classroom without a teacher, they ask the students who is supposed to be teaching and take down their name. Unit leaders handle student allegations of teacher misconduct, for example, regarding the use of corporal punishment or coming to school drunk (Mitchell 2017b). They also handle teacher concerns, such as cases of student misconduct and requests for locker keys. Unit leaders address these problems, involving management, where necessary; however, their primary function is teacher surveillance. In Management Committee meetings, unit leaders discuss their colleagues' conduct and participate in departmental ranking exercises. They also nominate teachers for awards, based on evidence from their surveillance activities.

While the role of student monitor is long associated with behavioural control (see Poluha 2004, 90; Mitchell 2017a, 164-6), the role of 'one-to-five' network leader is a recent innovation. Ketema teachers associated the introduction of the 'one-to-five' network system with pedagogical changes over the past 5 or 6 years, specifically around the use of group work. ${ }^{3}$ Seating in the classroom is organised around the network system, whereby one topranking student (the network leader) is assigned to support five or six lower-ranking peers at their desk. In this way, each student shares a desk with an academically successful model. For their peers, network leaders are a valuable source of explanations, advice, and answers for copying; classmates often turn to them before seeking help from the teacher. In Vygotskyan terms $(1978,86)$, they are 'more capable peers' who support others' learning within the zone of proximal development. In lessons, network leaders facilitate group work activities; they elicit inputs from their peers, and often act as scribe (for differences in role enactment, see Mitchell 2017a, 167-9). Network leaders may tap their classmates to bring their attention to the work, but aside from any active efforts on their part, their mere presence influences their peers. Even before the teacher enters the room, the network leaders turn to the correct page in the textbook; they stand to greet the teacher and respond quickly to instructions. In this sense, network leaders constantly model behaviour in line with teacher expectations.

\footnotetext{
3 'One-to-five' networks are a TPLF innovation, widely used outside education, for example, in agriculture, health, and policing (Maes et al. 2015). The use of peer support networks in school resonates with the longstanding use of peer mentoring within Orthodox church education, which may explain why this particular innovation has 'taken' where similar reforms in SSA have met with 'tissue rejection' (Schweisfurth 2011; Tabulawa 2013). Other studies in East Africa have also reported the increased use of group work in recent years (e.g. in Kenya, see Hardman et al. 2009).
} 
The DL positions work alongside others strategies of social control: 'disciplinary technologies' (Foucault 1995), through which members of the school community are 'described, judged, measured, compared with others [...] corrected, classified, normalized, excluded, etc.' (199). As illustrated above, mutual surveillance operates across all levels of the school: individuals monitor their colleagues and report to their seniors (monitors to tutors, unit leaders to management). The ranking of individuals in relation to their peers establishes positive and negative models at each tier of the system (model students, teachers, departments, schools). Positive models, such as network leaders, are examples for others to learn from and emulate; by the same logic, negative models (discussed below) are examples of how not to behave.

\subsection{Meetings in school}

Meetings are forums for sharing information, instructions, expectations, and concerns. They are 'arenas of struggle' (Ball 1987), conflict, and coalition; spaces for collective deliberation and decision-making - all of which are necessary or inevitable aspects of school life. The study included data (audio transcriptions, minutes, participant commentaries, and nonparticipant observations) from 38 meetings, including meetings of staff, the PSTA, and various committees (for details, see Mitchell 2017a, Appendix 4).

Table 2 Meetings in school

\begin{tabular}{|l|l|}
\hline Meeting type & Description \\
\hline PSTA & $\begin{array}{l}\text { Fortnightly meeting of the school's governing body (comprising the } \\
\text { Director, 2-3 teachers, 3-4 parents and 2 student representatives). } \\
\text { Discussion of activities in school, including examination performance } \\
\text { data, teacher performance appraisals, and staff/student disciplinary } \\
\text { cases. Decisions on budgetary matters. }\end{array}$ \\
\hline Staff & $\begin{array}{l}\text { Meeting every 2-3 weeks chaired by Director, mostly concerned with } \\
\text { management communications: reviewing recent activities, instructions } \\
\text { for forthcoming events. Based on evidence from internal supervision, } \\
\text { teachers are praised (e.g. for undertaking additional tasks) or criticised } \\
\text { (e.g. for lateness, using corporal punishment). Teachers also flag } \\
\text { concerns about conditions in school or management misconduct (e.g. } \\
\text { insufficient textbooks, timetabling errors, favouritism), and suggest } \\
\text { changes to policy/practice. Decisions reached through dialogue and/or } \\
\text { a vote. }\end{array}$ \\
\hline $\begin{array}{l}\text { Grade gim } \\
\text { gima }\end{array}$ & $\begin{array}{l}\text { Biannual teacher-facilitated forum in which all students in a grade } \\
\text { evaluate their teachers and peers according to management-supplied } \\
\text { criteria (part of the school's internal supervision system). }\end{array}$ \\
\hline $\begin{array}{l}\text { 'Parents' } \\
\text { Ceremony' }\end{array}$ & $\begin{array}{l}\text { Biannual event for family members. The Director, teachers and parents } \\
\text { share their evaluations of activities in school, raising concerns, offering } \\
\text { advice, and suggesting ways forward. Ceremony includes student } \\
\text { performances (songs, poems). }\end{array}$ \\
\hline
\end{tabular}




\begin{tabular}{|l|l|}
\hline Parents & $\begin{array}{l}\text { Meetings organised for the parents of a particular grade or tutor group } \\
\text { (chaired by Director or tutor, respectively). Participants share problems } \\
\text { and ideas for improvement. Discussion of positive and negative aspects } \\
\text { of individuals' or groups' conduct - especially students, but also } \\
\text { parents and teachers. Focus on collaborative problem solving. }\end{array}$ \\
\hline
\end{tabular}

Table 2 provides a descriptive overview of a selection of different types of meeting in school. As indicated, meetings involve all sections of the school community, and serve functions in relation to different aspects of school (and home) life. I found Lukes (2005) power analysis framework useful for exploring each stakeholder group's influence across these sites. Lukes (2005) proposes three dimensions of power:

One-dimensional power involves asserting preferences within boundaries established by others, for example, nominating a representative or voting on a motion.

Two-dimensional power consists in the capacity to shape decision-making arenas, for example, deciding which issues are open for debate, and who is permitted to have a say.

Three-dimensional power is an invisible mode of domination which operates at the level of individuals' notions of what is normal and acceptable. It involves securing individuals' consent to dominant power relations by affecting their values, motivations and sense of place in the world.

I refer to these dimensions of power in the following discussion of the participation and influence of the four key stakeholder groups.

\section{Management strategies of control}

Meetings enable the expression of diverse viewpoints, some of which run counter to management agendas. The disruptive potential of this is minimised by management's capacity to shape decision-making forums (i.e. two-dimensional power), most importantly, through the power of the chair. As chairperson, the Director sets the agenda and decides who can speak, when, for how long, and to what end. This enables him to open or close topics for debate, and decide which issues will be put to a vote. The Director determines the rules of engagement: he decides whose arguments are valid, and when further supporting evidence is needed. Laws and regulations are invoked as necessary to legitimate his own position and indicate where matters are beyond the decision-making authority of the school. Time is used strategically. For example, at a Parents' Ceremony, the Director invited participants to vote on the motion to raise school fees after he had spent half an hour presenting a case for doing so. Similarly, discussion of the unpopular teacher performance appraisal results was left until the end of a lengthy lunchtime staff meeting, when most teachers were too tired and hungry to protest (cf. Ball 1987, 109).

Another disciplinary technology which regularly features in meetings is gim gima (public evaluation), a mode of criticism introduced by the TPLF which combines Leninist and traditional Tigrayan elements (Young 1997). Gim gima involves upward and downward critique. Individuals' conduct is evaluated publicly for the purpose of 'bringing them to the right track' and collective learning. At meetings I attended teachers were criticised in front of colleagues for misdemeanours which included lateness, using corporal punishment, and 
failing to prevent students from wasting water. Positive models were also identified, for example, teachers who had shown particular zeal in their duties or secured donations for the school. The same tactic was used in parents' meetings, where the Director praised the exemplary, socially responsible behaviour of certain (mostly female) students, and criticised other (mostly male) students for bullying classmates or failing to do their homework. Public critique is used to elicit feelings of pride, envy or shame, thereby encouraging compliance with management agendas.

I refer to management agendas several times in the above analysis. A primary agenda is complying with external regulations and excelling against the performance criteria whereby the school is ranked against others in the woreda (local authority). Fairness for students is another concern. I was surprised to find that almost all the issues which students raised in gim gima or expressed in private to me were also raised by the Director himself in staff meetings as matters which needed to be addressed.

\section{Teachers: deliberative dialogue and collective decision-making}

After management, teachers are the stakeholder group with the greatest capacity to influence conditions in school. They are vocal in PSTA meetings, identifying development priorities and occasionally challenging management decisions. In staff meetings, they identify areas where further information or decisions are required for the smooth running of the school. They may also effect policy changes in areas not subject to tight external regulation, such as resource management. This occurs through deliberative dialogue and collective decisionmaking. For example, in one meeting the Director reminded staff about the end-of-year arrangements for collecting textbooks: students would be fined for loss or damages, and books with missing pages would not be accepted by the storekeeper. Requesting permission to speak, a young Maths teacher pointed out that if they proceeded in this way there would be a severe shortage of textbooks within two years. He suggested it would be better to collect and repair the damaged textbooks, and charge parents for duplicating any missing pages. The Director opened the issue for debate and several teachers shared their views. The discussion reflected a range of concerns: that a high textbook-to-student ratio be maintained; that the condition of textbooks be preserved; and that charges levied on parents were affordable. After weighing these points, teachers voted to change the policy in line with the Maths teacher's suggestion. This mode of participation - deliberative dialogue and collective decision-making - occurs in the absence of explicit external directives.

Teachers also use these forums to raise concerns about the conduct of colleagues, including management. At meetings I attended, members of management were criticised for rudeness, quarrelling amongst themselves, attempting to unfairly benefit relatives, and failing to discharge administrative duties with due care. These criticisms provoked denials or else admissions, apologies and commitments to change. Management cannot easily oppose or ignore the collective will of the staff, as the directors wish to maintain the good opinion of their colleagues who they work alongside each day. Teachers' comments in these forums reflect their concern for the fair distribution of responsibilities and benefits, effective resource management, and the maintenance of the school's image, especially in the eyes of parents. 


\section{The 'one-dimensional' power of students and parents}

The influence of students and parents is less free-ranging than that of the stakeholders discussed above, although a distinction must be made between the 'average' student or parent and their elected representatives. The inclusion of students on the PSTA began not long before the fieldwork started. The minutes of these meetings indicated that students' presence was yet to make a significant impact: they seldom spoke, and did so only to endorse the Director's position (see Mitchell 2017b). Parents were more vocal, their comments reflecting concerns for the budget and student welfare, amongst other things. For example, when the Director informed the PSTA that a Grade 5 teacher had been referred to the Discipline Committee after student complaints about his use of corporal punishment, two parents requested additional action. One mother argued:

If he is not in a position to correct himself by learning from his mistakes and bad acts, then on top of the measures taken by the Discipline Committee, he should also be warned through the community police. (PSTA Meeting, FN813)

This action was subsequently taken, illustrating parents' genuine capacity to affect conditions in school through this forum, providing their wishes are consistent with external policy requirements.

The decision-making authority of the typical parent is more limited. Participants at parents' meetings are given wide scope to comment on diverse aspects of school life. At meetings I attended, parents raised pedagogical issues, for example, about the lack of marking, and the repeated assignment of 'copying' tasks. They also shared their views on good parenting, advising others to ensure their children studied at home instead of watching television, and to avoid giving their children money to spend on sweets. These inputs were graciously received by the Director, who praised ideas which support his own view, and explained why divergent views were impracticable. Management is under no obligation to act upon such concerns: parental decision-making is limited to management-specified issues, such as nominating representatives or voting on the level of school fees.

Student influence is similarly regulated by management agendas. In grade gim gima they are asked to report teachers who break the rules, for example, by failing to wear their gown in class or conduct the requisite number of assessments (for a list of evaluation criteria, see Mitchell $[2016,5])$. These are management not student concerns. Student talk does range beyond the formal consultation agenda. For example, they regularly express dissatisfaction that persistently late or absent classmates are permitted to sit exams. However, they have no capacity to effect policy change. ${ }^{4}$ In short, gim gima and similar forums enable the expression of diverse student concerns, but management is under no obligation to act upon this information. Where management and student agendas coincide, such as issues of teacher misconduct (using corporal punishment, missing lessons), then action results from student complaints. This constitutes a genuine, if limited, capacity for students to hold teachers to account, to an extent which is unusual in SSA (Harber and Mncube 2012; Adzahlie-Mensah 2014) and elsewhere in the world (Harber 2010; Mitchell 2017b).

\footnotetext{
${ }^{4}$ Management wishes to maximise the promotion rate in order to raise the school's standing within the woreda.
} 
Although I have characterised typical student and parent influence as 'one-dimensional' power, in the sense of a limited capacity to voice preferences within frameworks established from above, the expressed concerns of these stakeholders are often raised or championed by others in spaces to which they do not have access. As mentioned above, management and teacher comments in staff meetings often demonstrate their concern for these stakeholders' interests.

\section{Patterns of participation and influence by age and gender}

Age and gender are associated with differential participation amongst the staff and parents. In staff meetings, male teachers speak more often than female teachers, and their comments more often challenge management. Elder teachers are more vocal than their younger colleagues, and they have a more prominent role in the arbitration of workplace disputes (Mitchell 2017a, 193-195). ${ }^{5}$ At parents' meetings, females out-number males 2:1, but males speak more frequently. One male parent observed:

I can see here most of the parents are females...The fathers of these children have little interest in coming to the school; this is one great problem. (Grade 8 Parents' Meeting, FN853)

In PSTA meetings the gender divide is less clear: the position of chair is occupied by a male parent, but the female parents are more outspoken (as in the above example, where a mother sought police involvement in a case of teacher misconduct). This contrasts with findings from elsewhere in SSA, where female parents in such bodies are largely characterised as mute participants (e.g. Rose 2003; Khan 2006).

Unlike the adult meetings discussed above, student meetings were not marked by gender inequities; if anything, female students were perhaps slightly more vocal than their male counterparts. These generational differences suggest a disruption of traditional gender roles (Mjaaland 2016), in line with national development goals (MOE 2015).

\section{Discussion and conclusion}

This article reported on how the participation and influence of local stakeholders is achieved and mediated by structures and processes in school. Positions of distributed leadership (DL) and meetings were identified as key contexts of participation; these were explored in relation to Foucault's (1995) and Lukes' (2005) theorisations of power. This section recapitulates and extends the analysis, locating practices at Ketema within the broader empirical literature, and discussing the methodological implications of this study.

In common with findings from some Anglo-American contexts (e.g. Hatcher 2005; Maxcy and Nguyen 2006; Harris 2013), positions of DL at Ketema are a means of control rather than democratisation. Alongside disciplinary technologies of surveillance, evaluation and ranking, DL reinforces the hierarchical command structure of the school. It is an extractive form of participation (Rose 2003): a means of mobilising the intellectual and material resources of the school towards management agendas, rather than ensuring

\footnotetext{
${ }^{5}$ The intergenerational dynamics at Ketema were similar to those described by Dull (2004) in the context of a teacher training college in Ghana: 'While respectful of older staff members...tutors were not afraid to confront administration and elders at staff meetings' (307).
} 
responsiveness to local priorities and values (MacBeath 1999; Woods 2004; Barrera-Osorio et al. 2009).

Nevertheless, stakeholders are not passive agents of management control. Lukes' (2005) framework helps to interrogate the forms of power available to different stakeholder groups. For the most part, students' and parents' influence is limited to one-dimensional power. These groups assert preferences within frameworks decided elsewhere. Meetings offer them the opportunity to express their views on diverse aspects of life in school; to suggest changes, and critique the conduct of teachers, management, and others. The extent to which this occurs is surprising, given the Ethiopian Government's widely-reported intolerance of dissent (e.g. Mosley 2015; Kalkidan 2017) and the lack of downward accountability in schools across much of SSA (Harber and MnCube 2012; Adzahlie-Mensah 2014). In providing a public forum for the criticism of hierarchical superiors, the practice of gim gima serves as an important mechanism for internal accountability (Young 1997; Abelmann and Elmore 1999). However, except in rare cases, students and parents do not decide which issues will be debated or put to a vote; and although they have fairly free reign to voice concerns, management acts upon these, or not, at its discretion.

In contrast, management exerts wide-ranging two-dimensional power, deciding when and where meetings are called, who is invited, who may speak, and to what end. This allows considerable scope to direct both the course and outcome of discussions. There is space for teachers to raise agenda items and participate in collective decision-making in areas which concern them, such as resource management and the fair distribution of benefits. In wishing to be respected and avoid unpleasant encounters, teachers are sensitive to how decisions made in staff meetings may be received by parents; similarly, management regularly raises student concerns (such as teacher lateness, the use of corporal punishment) in these forums. Thus, parents and students may vicariously influence the course of discussion in meetings, even when they are not present. Of course, decisions are only taken in areas not subject to external regulation.

In the system outlined above, three-dimensional power is exercised by the State, which influences individuals' beliefs about what is normal, legitimate and desirable by: defining the role expectations of each stakeholder group and identifying areas of legitimate concern; establishing the mechanisms and modalities of stakeholder participation in processes of consultation, evaluation and decision-making, and the limits of school-level autonomy; and establishing performative criteria by which schools are evaluated and ranked against others in the woreda (Niesche 2015). The general 'compliance' I found at Ketema across all sections of the school community reflects the efficacy of this system of control. A recent study (Ehren et al. 2016) praised the 'transparency' of school evaluation criteria in Ethiopia, which was singled-out as a model for other countries in the region. As the Ketema study illustrates, the clarity of external regulations and quality criteria reflects their social control function.

Methodologically, this study illustrates the importance of viewing the participation and influence of different stakeholder groups in interaction rather than focusing on a single group such as parents in isolation or an undifferentiated 'community' (e.g. Suzuki 2002; Yamada 2014): the interests and agendas of different groups are interrelated. Secondly, it indicates the value of investigating stakeholder participation and influence broadly across different 
participative spaces (e.g. positions of leadership, meetings); an ethnographic approach is useful for this.

\section{Acknowledgments}

I wish to express my sincere thanks to the students and staff of 'Ketema School' and the officials of the Tigray REB and WEO who supported this study. I am grateful to my supervisors, David Pedder and Alison Fox, and my former-colleague Micheal Abraham, for their insights and support throughout the study. Thanks to Clive Harber, Wasyl Cajkler, and the two anonymous referees who provided extremely valuable feedback on earlier drafts of this paper. This research was made possible through a PhD scholarship from the School of Education, University of Leicester.

\section{References}

Ethiopian authors are listed by their first names.

Abelmann, Charles, and Richard Elmore. 1999. When accountability knocks, will anyone answer? Consortium for Policy Research in Education, University of Pennsylvania.

Adzahlie-Mensah, Vincent. 2014. 'Being 'nobodies': school regimes and student identities in Ghana." PhD thesis, University of Sussex. Available at: http://sro.sussex.ac.uk/48419/ (Accessed: 9 July 2015)

Ball, Stephen. 1981. Beachside Comprehensive: a case study of secondary schooling. Cambridge: Cambridge University Press.

Ball, Stephen. 1987. The micro-politics of the school: towards a theory of school organization. London: Methuen.

Ball, Stephen. 1990. "Self-doubt and soft data: social and technical trajectories in ethnographic fieldwork." International Journal of Qualitative Studies in Education 3(2), 157171.

Barrera-Osorio, Felipe, Tazeen Fasih, Harry Anthony Patrinos, and Lucrecia Santibáñez. 2009. Decentralized decision-making in schools: the theory and evidence on school-based management. Washington, DC: World Bank.

Berihu Asgele, and Mewcha Amha. 2015. "Teachers in Politics: Impact of Political Party Membership on Teachers' Freedom and Stability. The Case of Nigste-Saba High School. Adwa, Tigray, Ethiopia." Journal of Education and Practice 6(13) 223-235.

Braun, Virginia, and Victoria Clarke. 2006. "Using thematic analysis in psychology." Qualitative Research in Psychology 3(2), 77-101.

Burgess, Robert. 1983. Experiencing comprehensive education: a study of Bishop McGregor School. London: Methuen.

Crick, Bernard. 2002. Democracy. Oxford, Oxford University Press.

Daun, Holger, and Karen Mundy. 2011. Educational governance and participation.

Stockholm: Institutionen för internationell pedagogik, Stockholms universitet. 
Davies, Lynn. 1999. “Comparing Definitions of Democracy in Education”, Compare 29(2): $127-40$.

Davies, Lynn, Clive Harber, and Michele Schweisfurth. 2002. Learning democracy and citizenship: international experiences. Oxford: Symposium Books.

Deakin Crick, Ruth, Steven Barr, Howard Green, and David Pedder. 2016. "Evaluating the wider outcomes of schools: complex systems modelling for leadership decisioning." Educational Management, Leadership and Administration, DOI: $10.1177 / 1741143215597233$.

De Waal, Alex. 2013. "The theory and practice of Meles Zenawi." African Affairs 112(446), 148-155.

Dull, Laura J. 2004. "Democracy and discipline in Ghanaian education." International Journal of Educational Development 24(3), 303-314.

Ehren, Melanie, David Eddy-Spicer, Mukdarut Bangpan, and Andy Reid. 2016. "School inspections in low- and middle-income countries: Explaining impact and mechanisms of impact." Compare. Early view. DOI: 10.1080/03057925.2016.1239188.

Fielding, Michael, and Marica Prieto. 2002. "The Central Place of Student Voice in Democratic Renewal: A Chilean Case Study." Learning Democracy and Citizenship: International Experiences, edited by Lynn Davies, Clive Harber, and Michele Schweisfurth. Oxford: Symposium Books.

Foucault, Michel. [1977] 1995. Discipline and punish: the birth of the prison. New York: Vintage Books.

Gaventa, John. 2005. Reflections of the uses of the 'Power Cube' approach for analyzing the spaces, places and dynamics of civil society participation and engagement. CFP Evaluation Series 4. The Hague, Netherlands: MBN Secretariat.

Gaventa, John. 2006. "Finding the spaces for change: a power analysis." IDS Bulletin, 37(6), 23-33.

Gaventa, John, and Rosemary McGee. 2013. "The impact and effectiveness of transparency and accountability initiatives." Development Policy Review 31(1), 3-28.

Hammersley, Martiyn, and Paul Atkinson. 2007. Ethnography Principles in Practice: Third Edition. Hoboken: Taylor \& Francis.

Harber, Clive. 2002. "Education, democracy and poverty reduction in Africa." Comparative Education 38(3), 267-76.

Harber, Clive, and Vusi Mncube. 2012. Education, democracy and development: Does education contribute to democratisation in developing countries? Oxford: Symposium Books.

Harber, Clive. 2010. "Long time coming: children as only occasional decision-makers in schools" in Children as decision makers in education: sharing experiences across cultures, edited by Sue Cox, Anna Robinson-Pant, Caroline Dyer, and Michele Schweisfurth. London: Continuum Press. 
Hardman, Frank, Jan Abd-Kadir, Catherine Agg, James Migwi, Jacinta Ndambuku, and Fay Smith. 2009. "Changing pedagogical practice in Kenyan primary schools: the impact of school-based training." Comparative Education 45:1, 65-86.

Hargreaves, David. 1967. Social relations in a secondary school. London: Routledge \& K. Paul.

Hargreaves, David. 1999. "The knowledge-creating school." British Journal of Educational Studies 47(2), 122-144.

Harris, Alma. 2013. “Distributed leadership friend or foe?” Educational Management Administration \& Leadership 41(5): 545-554.

Hatcher, Richard. 2005. "The distribution of leadership and power in schools." British Journal of Sociology of Education 26(2), 253-267.

Jeilu Oumer. 2009. The challenges of free primary education in Ethiopia. Paris: UNESCO, IIEP.

Kalkidan Yibeltal. 2017. "Never Again? Inside Ethiopia's "retraining” programme for thousands of detained protesters." African Arguments, 26 January. Available at: http://africanarguments.org/2017/01/26/never-again-inside-ethiopias-retraining-programmefor-thousands-of-detained-protesters/ (Accessed: 30 January 2017)

Khan, Faryal. 2006. "Who participates in school councils and how?" Prospects: Quarterly Review of Comparative Education 36(1), 97-119.

Knoblauch, Hubert. 2005. "Focused Ethnography." Forum Qualitative Sozialforschung / Forum: Qualitative Social Research 6(3), Art. 44. Available at: http://nbnresolving.de/urn:nbn:de:0114-fqs0503440 (Accessed: 18 January 2016).

Lewin, Kevin. 2009. "Access to education in sub-Saharan Africa: patterns, problems and possibilities." Comparative Education 45(2), 151-174.

Lukes, Steve. 2005. Power: a radical view (Second Edition). New York: Palgrave Macmillan.

MacBeath, John. 1999. Schools must speak for themselves: the case for school selfevaluation. London: Routledge.

MacBeath, John, and Neil Dempster. 2009. Connecting leadership and learning: principles for practice. London: Routledge.

Maes, Kenneth, Svea Closser, Ethan Vorel, and Yihenew Tesfaye. 2015. “A Women's Development Army: narratives of Community Health Worker investment and empowerment in rural Ethiopia." Studies in Comparative International Development 50(4), 455-478.

Masue, Orest, and Steinar Askvik. 2016. "Are school committees a source of empowerment? Insights from Tanzania." International Journal of Public Administration. Early view. DOI: 10.1080/01900692.2016.1201839. 
Maxcy, Brendan, and Thu Su'o'ng Thi Nguyen. 2006. "The politics of distributing leadership: Reconsidering leadership distribution in two Texas elementary schools." Educational Administration Abstracts 41(1), 163-196.

Mitchell, Rafael. 2015. "The implications of school improvement and school effectiveness research for primary school principals in Ethiopia." Educational Review 67(3), 328-342.

Mitchell, Rafael. 2016. "Sharing responsibility: student leadership and accountability mechanisms at an urban government primary school in Tigray, Ethiopia." Paper presented at the School of Education Annual Research Conference, University of Leicester, May. Available at: https://lra.le.ac.uk/handle/2381/37780 (Accessed: 24 July 2016).

Mitchell, Rafael. 2017a. "An ethnographic case study of the agendas, participation and influence of stakeholders at an urban government primary school in Tigray, Ethiopia." $\mathrm{PhD}$ thesis, University of Leicester.

Mitchell, Rafael. 2017b. "Radical student participation: lessons from an urban government primary school in Tigray, Ethiopia." Compare (submitted).

Mitra, Dana. 2004. "The significance of students: can increasing student voice in schools lead to gains in youth development?” Teachers College Record 106(4), 651-688.

Mjaaland, Thera. 2016. "Negotiating gender norms in the context of equal access to education in north-western Tigray, Ethiopia." Gender and Education Early view. Available at: DOI: http://dx.doi.org/10.1080/09540253.2016.1175550.

MOE. 2005. Education Sector Development Programme III (ESDP III), 2005 - 2010. Addis Ababa: MOE.

MOE. 2007. Excellence in Ethiopian schools - Improving performance through school selfassessment: Handbook for guidance of Self-Assessment and School Improvement Planning. Addis Ababa: MOE.

MOE. 2008. General Education Quality Improvement Package (GEQIP). Addis Ababa: MOE.

MOE. 2010. School Improvement Program Guidelines (Final Draft): Improving the quality of education and student results for all children at primary and secondary schools. Addis Ababa: MOE.

MOE. 2012. Education Statistics Annual Abstracts 2004 EC (2011/2012). Addis Ababa: MOE.

MOE. 2015. Education Sector Development Program V (ESDP V) 2015/2016 - 2019/2020. Addis Ababa: MOE.

Mosley, Jason. 2015. "Ethiopia's elections are just an exercise in controlled political participation.” The Guardian, 22 May. Available at: https://www.theguardian.com/globaldevelopment/2015/may/22/ethiopia-elections-controlled-political-participation (Accessed: 1 September 2016)

Niesche, Richard. 2015. "Governmentality and "My School": school principals in societies of control." Educational Philosophy and Theory, 47(2), 133-145. 
Omolewa, Michael. 2007. "Traditional African modes of education: their relevance in the modern world." International Review of Education 53(5-6), 593-612.

Overseas Development Institute (ODI). 2011. Ethiopia's progress in education: A rapid and equitable expansion of access. London: ODI.

Poluha, Eva. 2004. The power of continuity: Ethiopia through the eyes of its children. Uppsala, Sweden: Nordiska Afrikainstitutet.

Pryor, John. 2005. "Can community participation mobilise social capital for improvement of rural schooling? A case study from Ghana." Compare 35(2), 193-203.

Rose, Pauline. 2003. "Community participation in school policy and practice in Malawi: balancing local knowledge, national policies and international agency priorities." Compare 33(1), 47-64.

Rudduck, Jean, and Donald McIntyre. 2007. Improving learning through consulting pupils. London: Routledge.

Schweisfurth, Michele. 2011. "Learner-centred education in developing country contexts: from solution to problem?" International Journal of Educational Development 31(5), 425432.

Stake, Robert. 1995. The art of case study research. Thousand Oaks: Sage Publications.

Stenhouse, Lawrence. 1978. "Case Study and Case Records: towards a contemporary history of education.” British Educational Research Journal 4(2), 21-39.

Suzuki, Ikuko. 2002. "Parental participation and accountability in primary schools in Uganda." Compare 32(2), 243-59.

Swift-Morgan, Jennifer. 2006. "What community participation in schooling means: insights from southern Ethiopia." Harvard Educational Review 76(3), 339-368.

Tabulawa, Richard. 2003. "International aid agencies, learner-centred pedagogy and political democratisation: a critique." Comparative Education 39(1), 7-26.

Tabulawa, Richard. 2013. Teaching and learning in context: why pedagogical reforms fail in Sub-Saharan Africa. Oxford: CODESRIA.

Taylor, Aleesha. 2009. "Questioning participation: exploring discourses and practices of community participation in education reform in Tanzania" in Critical approaches to comparative education, edited by Frances Vavrus and Lesley Bartlett. Basingstoke: Palgrave Macmillan.

Tekeste Negash. 2006. Education in Ethiopia: from crisis to the brink of collapse. Uppsala: Nordiska Afrikainstitutet. Available at: http://www.divaportal.org/smash/get/diva2:240545/FULLTEXT02.pdf (Accessed: 24 July 2016).

UNICEF. 1997. The progress of nations. New York: UNICEF.

Vaughan, Sarah. 2011. "Revolutionary democratic state-building: party, state and people in the EPRDF's Ethiopia.” Journal of Eastern African Studies 5(4), 619-640. 
Verger, Antoni, Mario Novelli, and Hülya K. Altinyelken. 2012. Global education policy and international development: new agendas, issues, and policies. New York: Bloomsbury Academic.

Vygotsky, Lev. 1978. Mind in society: the development of higher psychological processes. Cambridge: Harvard University Press.

Woodhouse, Joan, and David Pedder. 2016. "Early career teachers' perceptions and experiences of leadership development: balancing structure and agency in contrasting school contexts." Research Papers in Education. Early view. DOI:

10.1080/02671522.2016.1225794

Woods, Philip. 2004. "Democratic leadership: drawing distinctions with distributed leadership." International Journal of Leadership in Education 7(1), 3-26.

Woods, Philip, and Glenys Woods. 2013. "Deepening distributed leadership: A democratic perspective on power, purpose and the concept of the self." Vodenje v vzgoji in izobraževanju (Leadership in Education) 2, 17-40. Available at:

https://www.academia.edu/3322586/Deepening_Distributed_Leadership_A_democratic_pers pective on power_purpose and the concept_of the self (Accessed 19/03/17)

Wolcott, Harry F. 1967. A Kwakiutl village and school. New York: Holt, Rinehart and Winston.

Wolcott, Harry. F. 1995. The art of fieldwork. Walnut Creek, AltaMira Press.

Young, John. 1997. Peasant revolution in Ethiopia: the Tigray People's Liberation Front, 1975-1991. Cambridge: Cambridge University Press.

Yamada, Shoko. 2014. "Determinants of "community participation": the tradition of local initiatives and the institutionalisation of school management committees in Oromia Region, Ethiopia." Compare 44(2), 162-185.

Zapp, Mike. 2017. "The World Bank and Education: Governing (through) knowledge." International Journal of Educational Development 53(1), 1-11. 